\title{
Analysis of Coastline Change in Klungkung Regency
}

\author{
I Made Ardantha ${ }^{1}$, Putu Aryastana ${ }^{2}$, Anak Agung Sagung Dewi Rahadiani ${ }^{3}$, Kadek Windy \\ Candrayana $^{4}$ \\ \{madeardantha@gmail.com¹,putuaryastana@yahoo.com²,dewi_rahadiani@yahoo.com³ ${ }^{3}$ \}
}

Warmadewa University, Department of Civil Engineering, Denpasar-Bali, Indonesia ${ }^{123}$

Udayana University, Master Student Department of Civil Engineering, Denpasar-Bali, Indonesia ${ }^{4}$

\begin{abstract}
Visual interpretation of remote sensing data is very popular and widely used to detect, extract and monitor changes in shoreline. Commonly used satellite images include: IRS, Landsat TM and ETM +, IKONOS, Quickbird, Worldview2 and Geoeye-1. To find out the changes in coastline and coastal erosion rates in Klungkung regency was carried out by comparing two satellite images, namely SPOT 5 satellite image data in 2009 having a spatial resolution of $10 \mathrm{~m}$ and SPOT 6/7 in 2015 which resolution up to $1.5 \mathrm{~m}$ with digital on screen extraction method. This research contributes to local government and central government as basic data in making decisions for handling coastal areas. The average shoreline change that occurs in Klungkung regency is 22.15 $\mathrm{m}$, while the average coastal erosion rate in Klungkung regency is $3.16 \mathrm{~m} / \mathrm{year}$.
\end{abstract}

Keywords: Extraction, Klungkung, SPOT

\section{Introduction}

The coastline is a line of contact between soil and water bodies that always changes rapidly at the coastal area and is difficult to capture, so accurate detection and periodic monitoring are very important to do to determine the dynamics and processes of the coastal area [1]. Visual interpretation of remote sensing data is very popular and widely used in the depiction of shoreline changes. Remote sensing techniques are now available to detect, extract, and monitor coastlines [2].

Several studies in coastline detection, extraction and monitoring using satellite imagery have been carried out to find out that this technique is an efficient technique. Indian Remote Sensing (IRS) satellite data in 1999, 2000, 2003, 2005 and 2006 was used to analyze shoreline changes in the coastal area between Kanyakumari and Tutikorin, India [1]. IKONOS satellite imagery with a resolution of $1 \mathrm{~m}$ is used to extract the coastline in the Lake Erie coastal area [3]. Landsat TM images in 1987, 1990, 1992 and Landsat ETM + images in 1999, 2002, 2004, 2006 was used to analyze and model the coastline and reverse coastline by using Digital Shoreline Analysis System (DSAS) method [4].

The WordView-2 image is also used to extract water levels in the Antarctic coastal area using the Normalized Difference Water Index (NDWI) approach [5]. The use of Landsat 5 TM images with the Automated Water Extraction Index (AWEI) method to extract water levels automatically [6]. The combination of aerial photography and satellite imagery (IKONOS, Quick bird, Worldview2 and Geoeye-1) was used to interpret shoreline changes in Wotje Atoll, Marshall Islands [7]. Water level extraction techniques using the Iterative Self- 
Organizing Data Analysis Technique (ISODATA) approach in Wordview-2 satellite images in the North Adriatic Sea, City of Revenna, Italy [8]. Landsat imagery is very often used to monitoring shoreline changes in Indonesia, such as: detects changes in coastline in Jembrana regency, Bali [9], analyzing shoreline changes in Bengkulu city [10], analyzed changes in the coastline in the Banyuasin River Estuary in southern Sumatra [11], study of coastline changes in Mawasangka district, Central Buton regency [12], monitoring shoreline changes on the coast of Pasuruan regency, Sidoarjo regency and Surabaya city by overlay method [13].

In this study an analysis of the average coastline changes and the average coastal erosion that occurred in Klungkung regency using SPOT 5 satellite imagery in 2009 and SPOT 6/7 in 2015 by using the on screen digital extraction method.

\section{Methods}

\subsection{Study area}

The study area is located along the coastal area of Klungkung regency, Bali province. The UTM boundary area of the study area is $320720.96 \mathrm{~m} \mathrm{E}, 9051762.47 \mathrm{~m} \mathrm{~S}$ up to $332624 \mathrm{~m}$ E, $9054467.60 \mathrm{~m} \mathrm{~S}$. The map of the study area is presented in Figure 1.

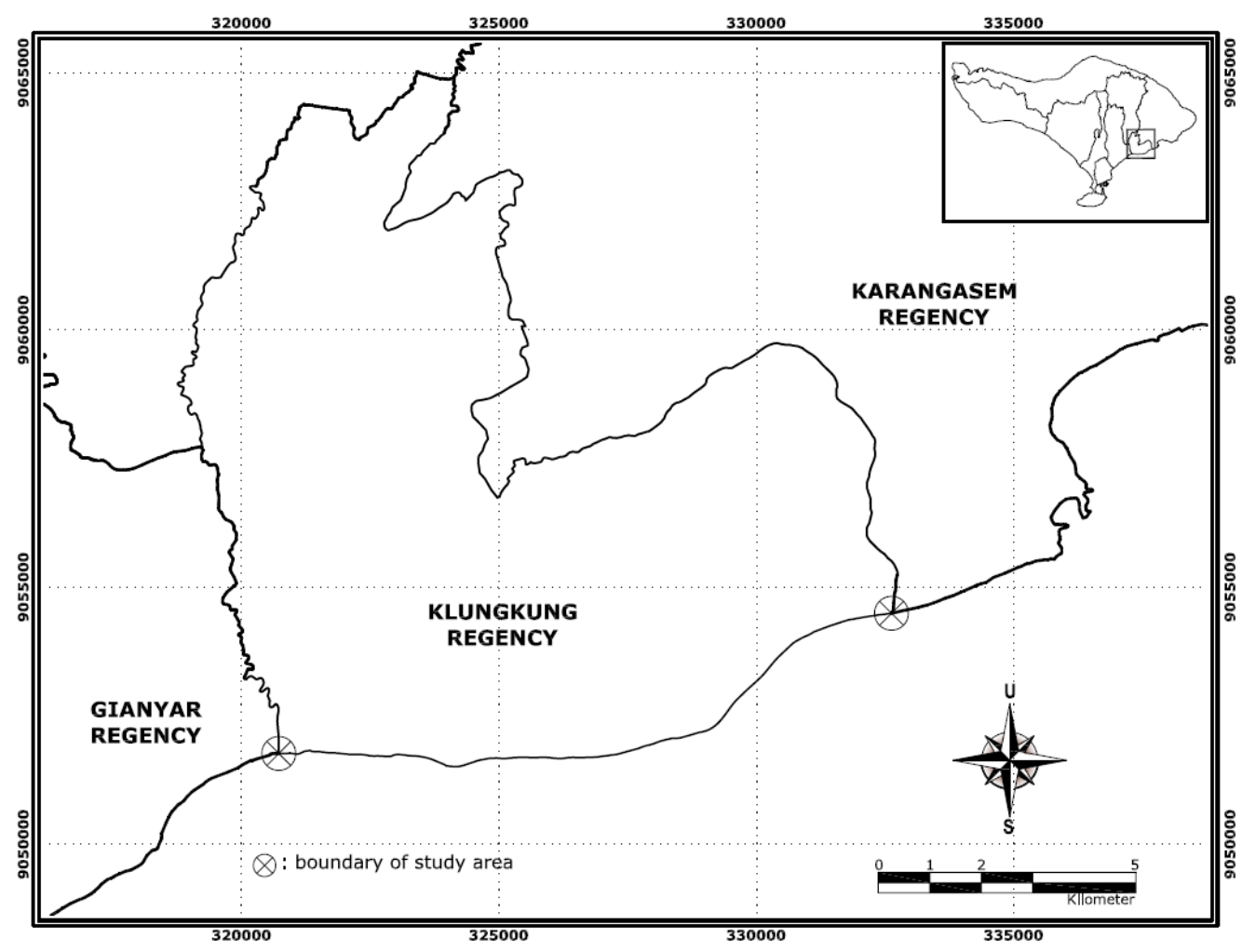

Fig. 1. Study area 


\subsection{Satellite image}

This study used SPOT 5 satellite imagery in 2009 with a resolution of $10 \mathrm{~m}$ at the date of acquisition 15 June 2018 at 2:20 am, and SPOT 6 in 2015 with a resolution of 1.5 meters at the acquisition date of 19 March 2015 at 9:18 am, also SPOT 7 in 2015 with a resolution of 1.5 meters at the acquisition date of February 8, 2015 at 9:20 am.

\subsection{Image processing}

The step of image processing to produce information about coastline changes in Klungkung regency can be seen in Figure 2. Coastline extraction uses the on-screen digital method. Analysis of shoreline changes using overlaying images of SPOT 2009 and 2015.

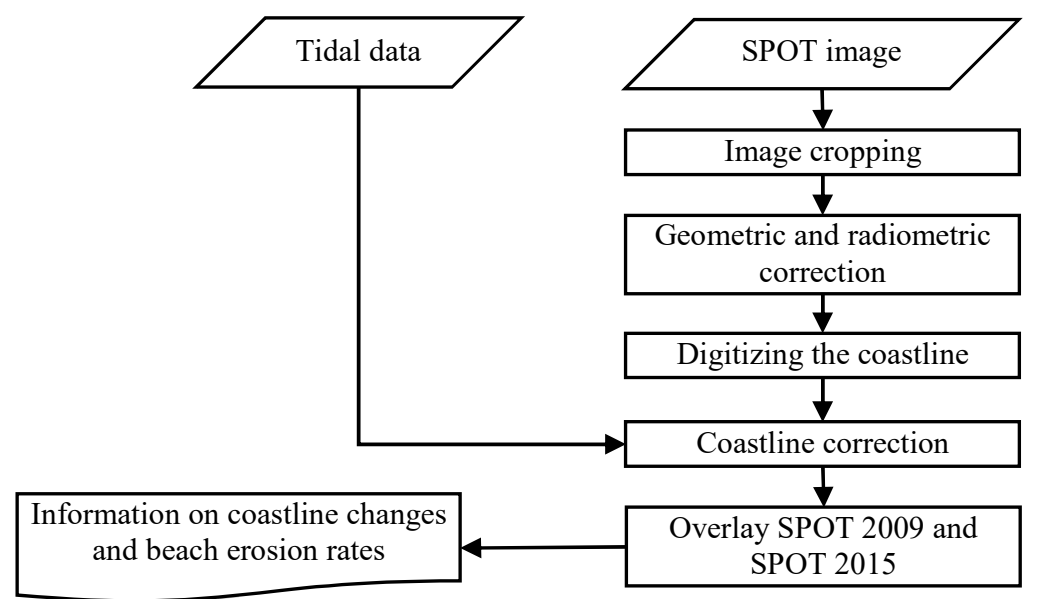

Fig. 2. Flowchart to obtain shoreline changes and coastal erosion rates

\section{Result and Discussion}

\subsection{Coastline correction}

Coastline correction is due to the tidal process. The shift distance of the water line correction $(\mathrm{Y})$ is calculated using the equation [14]:

Where:

$$
Y=\left(T k-\left(\frac{T k}{T b}-T x\right) \times T a n \varnothing\right)
$$

Y : shift distance (m)

Tk : high water level in sectional coastal area (m)

$\mathrm{Tb}$ : high water level in Benoa Harbor (m)

$\mathrm{Tx}$ : tidal datum when the image was acquired $(\mathrm{m})$

TanØ: coastal slope value in Klungkung regency is divided into several coastal segments as shown in Figure 3.

The results of the calculation of coastline correction can be seen in Table 1 . 


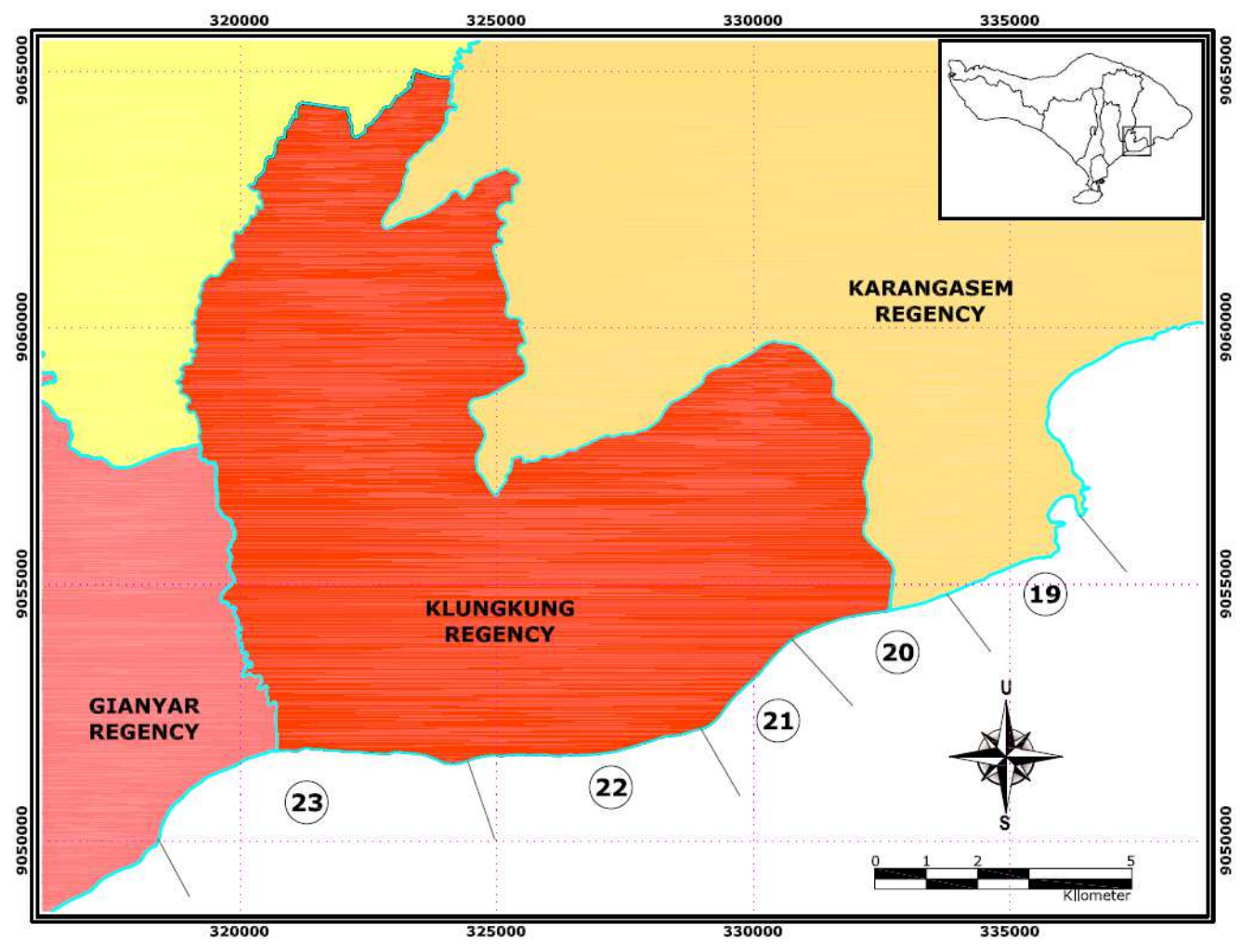

Fig. 3. Section division for coastal slope values in Klungkung regency

Table 1. Coastline correction results

\begin{tabular}{cccccccc}
\hline \multirow{2}{*}{ Section } & \multirow{2}{*}{ Slope } & \multirow{2}{*}{ Tk(m) } & \multirow{2}{*}{ Tb (m) } & \multicolumn{3}{c}{ Tx (m) } & \multicolumn{2}{c}{ Y (m) } \\
\cline { 5 - 8 } & & & & $\mathbf{2 0 0 9}$ & $\mathbf{2 0 1 5}$ & $\mathbf{2 0 0 9}$ & $\mathbf{2 0 1 5}$ \\
\hline 20 & 10 & 2.6 & 2.6 & 1.9 & 2.1 & 10.50 & 7.50 \\
21 & 15 & 2.6 & 2.6 & 1.9 & 1.0 & 11.20 & 25.60 \\
22 & 18 & 2.6 & 2.6 & 1.9 & 1.0 & 4.90 & 11.20 \\
23 & 18 & 2.6 & 2.6 & 1.9 & 1.0 & 4.90 & 11.20 \\
\hline
\end{tabular}

\subsection{Coastline changes and erosion rate analysis}

Overlaying coastline maps for SPOT imagery in 2009 and 2015 was obtained after making coastline corrections, as shown in the picture below: 


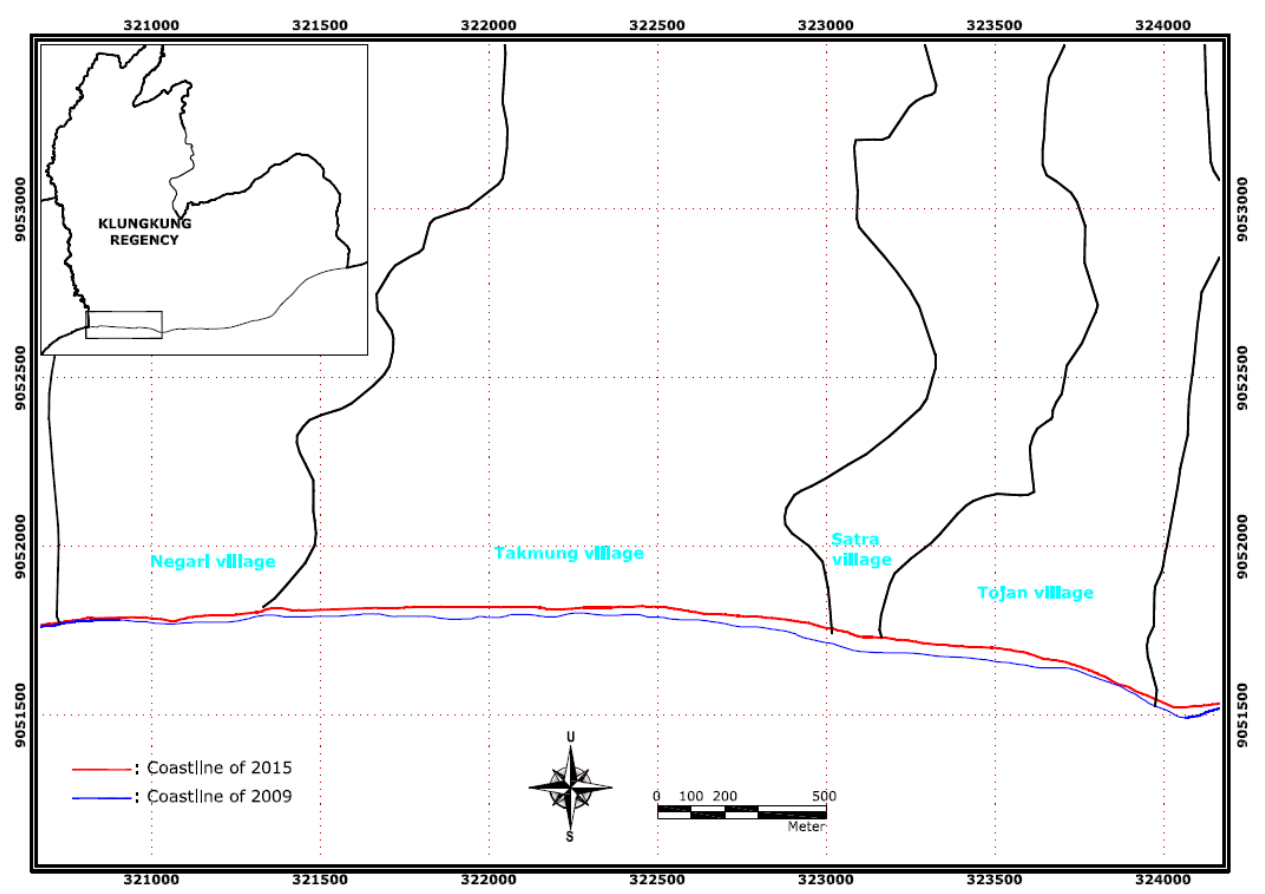

Fig. 4. Coastline changes map in Negari, Takmung, Satra and Tojan villages

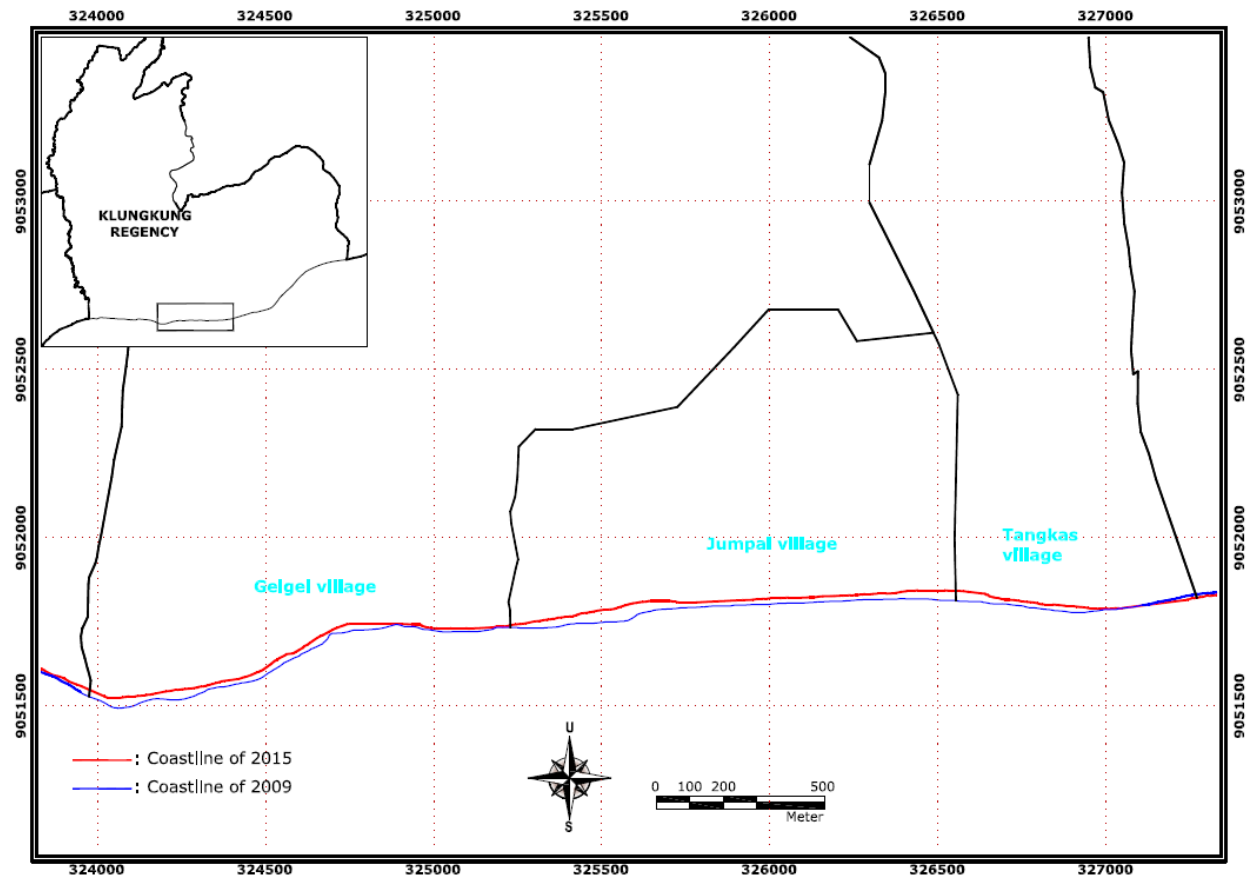

Fig. 5. Coastline changes map in Gelgel, Jumpai and Tangkas villages 


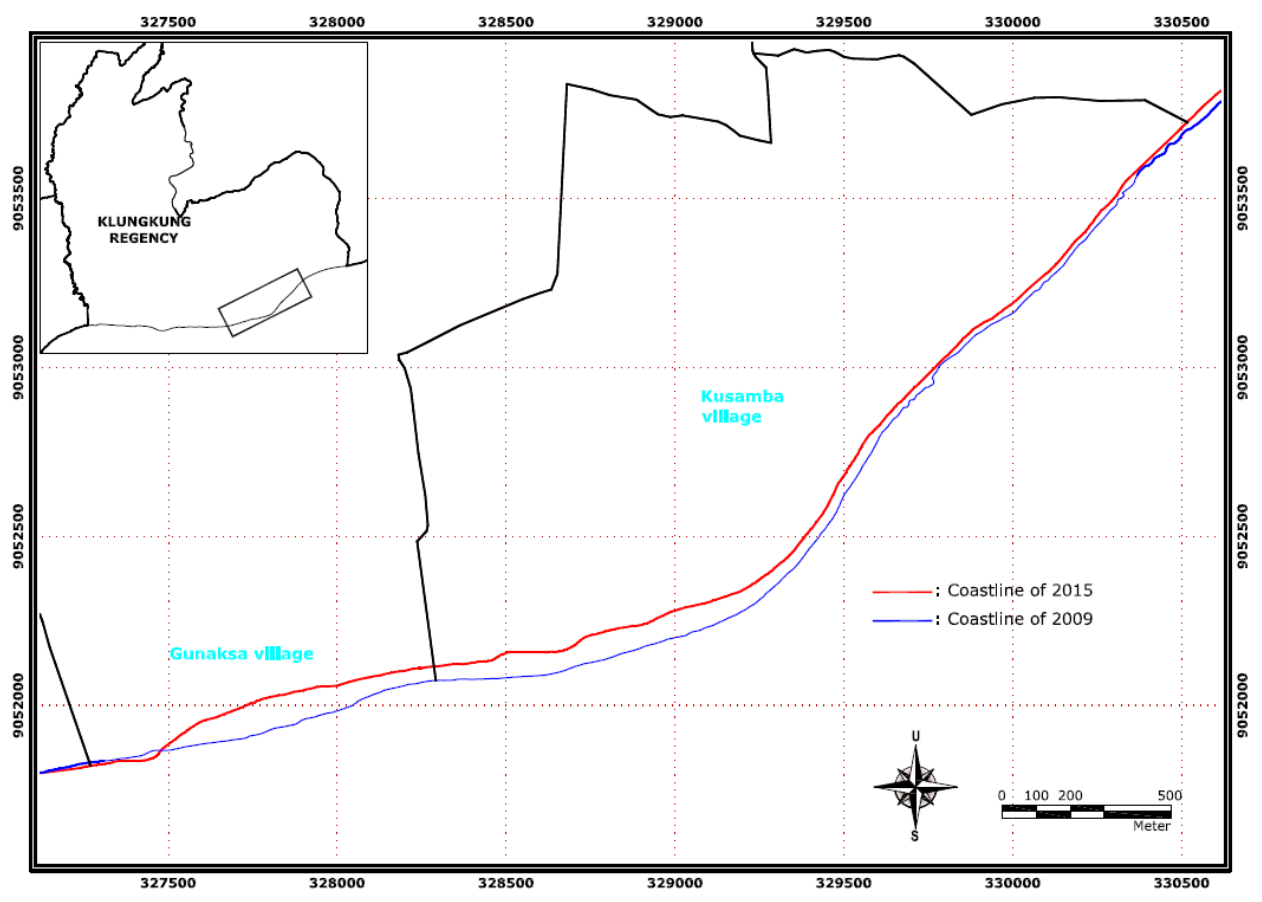

Fig. 6. Coastline changes map in Desa Gunaksa and Kusamba villages

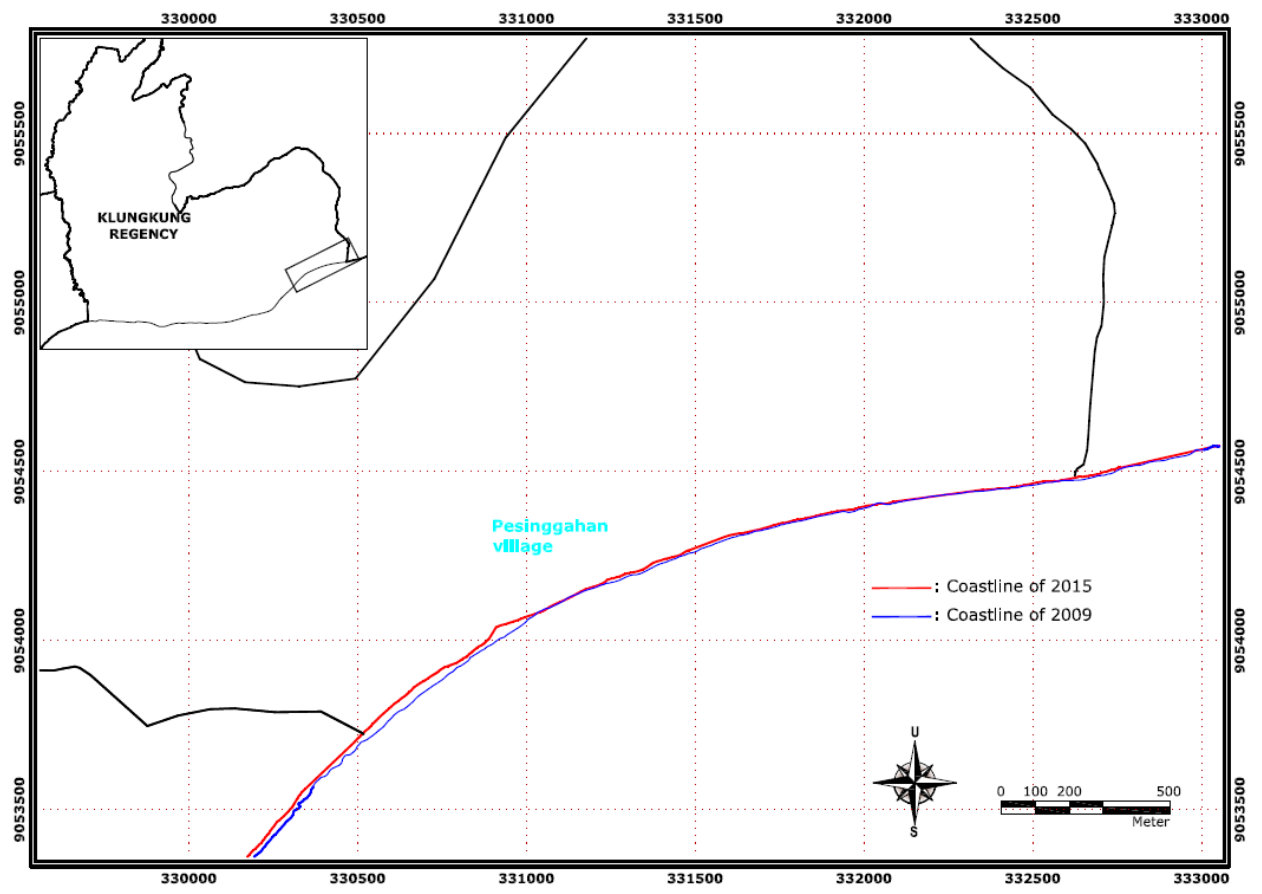

Fig. 7. Coastline changes map in Pesinggahan villages 
Figure 4 shows that there was a coastline decline from 2009 to 2015 that occurred in Negari, Takmung, Satra and Tojan villages. Coastal erosion also occurred in Gelgel, Jumpai and Tangkas villages, but some parts of Tangkas village coastal area that has accretion (Figure 5). Figure 6 shows the occurrence of a coastline retreat that occurred in Gunaksa and Kusamba villages. The coastal areas of Pesinggahan village mostly run into erosion, but there is a small part of the coastal area that has accretion (Figure 7). The average shoreline changes and the average erosion rate in each coastal area can be seen in the following Table 2.

Table 2. Coastline changes and coastal erosion rates in Klungkung regency

\begin{tabular}{cllcc}
\hline No & Village & Coastal area & $\begin{array}{c}\text { The rate of coastline } \\
\text { changes }(\mathbf{m})\end{array}$ & $\begin{array}{c}\text { The rate of erosion } \\
(\mathbf{m} / \text { year })\end{array}$ \\
\hline 1 & Pesinggahan & Pesinggahan & 7.12 & 1.02 \\
2 & Kusamba & Kusamba & 32.74 & 4.68 \\
3 & Gunaksa & Gunaksa & 35.05 & 5.01 \\
4 & Tangkas & Gunaksa-Jumpai & 7.51 & 1.07 \\
5 & Jumpai & Jumpai & 24.11 & 3.44 \\
6 & Gelgel & Watu Klotok & 16.06 & 2.29 \\
7 & Tojan & Watu Klotok & 27.56 & 3.94 \\
8 & Satra & Sidayu & 32.39 & 4.63 \\
9 & Takmung & Lepang & 27.17 & 3.88 \\
10 & Negari & Tegal Besar & 11.84 & 1.69 \\
\multicolumn{7}{r}{ Average } & $\mathbf{2 2 . 1 5}$ & $\mathbf{3 . 1 6}$ \\
\hline
\end{tabular}

The average coastline change based on the results of 2009 and 2015 SPOT image analysis in Klungkung regency is $22.15 \mathrm{~m}$, while the average coastal erosion rate in Klungkung regency is $3.16 \mathrm{~m} /$ year. The largest coastline changes and erosion rate occurred in Gunaksa village, which amounted to $35.05 \mathrm{~m}$ and $5.01 \mathrm{~m} /$ year, while the smallest coastline change and erosion rate occurred in the Pesinggahan village which amounted $7.12 \mathrm{~m}$ and 1.02 $\mathrm{m} /$ year. Field verification shows that there is a match between the analysis and ground survey of erosion event occurred in Klungkung regency. Figure 8 shows the occurrence of coastal erosion on the coast of Gunaksa, Gelgel and Tangkas.

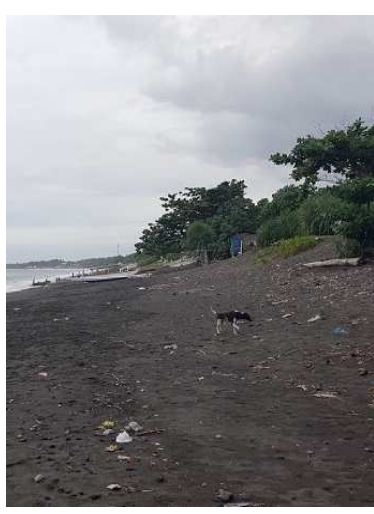

(a)

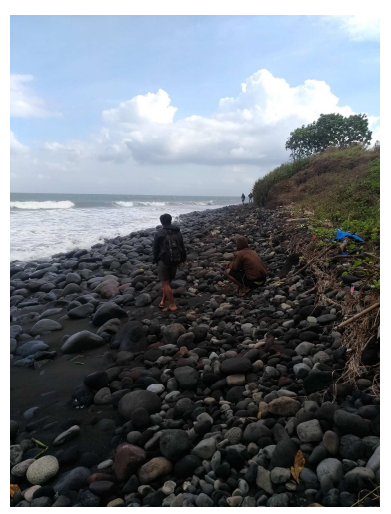

(b)

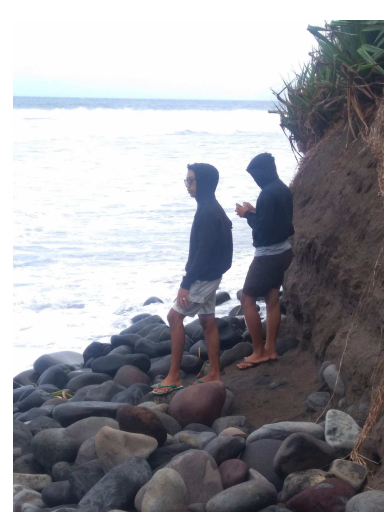

(c)

Fig. 8. Field verification, (a) Gunaksa beach, (b) Gelgel beach, (c) Tangkas beach 
The coastal erosion that occurred in Klungkung regency was a result of the movement of currents and waves that hit the coastal area. This is be in accordance with the research of Nugraha which uses Landsat satellite imagery in 1995, 2005, 2015 using the Extention Shoreline Analysis System (DSAS) method to obtain a coastline change rate due to coastal erosion of $-0.8833 \mathrm{~m} /$ year until $-8.8795 \mathrm{~m} /$ year [15]. Utilization of SPOT satellite imagery has provided information about coastline changes from 2009 and 2015 in the regencies of Buleleng, Gianyar, Tabanan, Jembrana, Karangasem, Badung and Denpasar City, so that it can be used as basic data in management of coastal protection [14] [16] [17] [18] [19] [20].

\section{Conclusion}

Based on the analysis results by using SPOT 2009 and SPOT 2015 images, the average coastline changes that occurred in Klungkung regency was $22.15 \mathrm{~m}$, while the average coastal erosion rate in Klungkung regency was $3.16 \mathrm{~m} /$ year.

\section{Acknowledgments}

The author would like to thank the Warmadewa University Research Institute for providing research grants. Thanks also to the Balai Wilayah Sungai Bali Penida for supporting satellite data and coastal area names.

\section{References}

[1] Mujabar, P. S., Chandrasekar, N.: Shoreline change analysis along the coast between Kanyakumari and Tuticorin of India using remote sensing and GIS. Arab J Geosci 6, pp. 647-664 (2013)

[2] Gens, R.: Remote sensing of coastlines: detection, extraction and monitoring. International Journal of Remote Sensing Vol. 31(7), pp. 1819-1836 (2010)

[3] Di, K., Wang, J., Ma, R., Li, R.: Automatic Shoreline Extraction from High-Resolution IKONOS Satellite Imagery. In : ASPRS 2003 Annual Conference Proceedings, Anchorage, Alaska (2003)

[4] Ahmad, S., Lakhan, V.: GIS-Based Analysis and Modeling of Coastline Advance and Retreat Along the Coast of Guyana. Marine Geodesy 35, pp. 1-15 (2012)

[5] Jawak, S., Luis, A.: A Rapid Extraction of Water Body Features From Antarctic Coastal Oasis Using Very High-Resolution Satellite Remote Sensing Data. In : International Conference on Water Resorces, Coastal and Ocean Engineering (ICWRCOE 2015), vol. 4, pp.125 - 132 (2015)

[6] Feyisa, G., Meilby, H., Fensholt, R., Proud, S.: Automated Water Extraction Index: A new technique for surface water mapping using Landsat imagery. Remote Sensing of Environment 140, pp. 23-35 (2014)

[7] Ford, M.: Shoreline changes interpreted from multi-temporal aerial photographs and high resolution satellite images: Wotje Atoll, Marshall Islands. Remote Sensing of Environment 135, pp. 130-140 (2013)

[8] Sekovski, I., Stecchi, F., Mancini, F., Rio, L.: Image classification methods applied to shoreline extraction on very high-resolution multispectral imagery. International Journal of Remote Sensing Vol. 35(10), pp. 3556-3578 (2014)

[9] Suniada, K.: Deteksi Perubahan Garis Pantai di Kabupaten Jembrana Bali dengan Menggunakan Teknologi Penginderaan Jauh. JURNAL KELAUTAN NASIONAL Vol. 10(1), pp. 13-19 (2015) 
[10] Syukhriani, S., Nofridiansyah, E., Sulistyo, B.: Analisis Data Citra Landsat untuk Pemantauan Perubahan Garis Pantai di Kota Bengkulu. Jurnal Enggano Vol. 2(1), pp. 90-100 (2017)

[11] Sihombing, M., Agussalim, A., Affandi, A.: Perubahan Garis Pantai Menggunakan Citra Satelit Landsat Multi Temporal di Daerah Pesisir Sungai Bungin Muara Sungai Banyuasin, Sumatera Selatan. MASPARI JOURNAL 9(1), pp. 25-32 (2017)

[12] Kulmawapa, R., Afu, L., Takwir, A.: Studi Perubahan Garis Pantai dengan Pendekatan Penginderaan Jauh di Wilayah Pesisir Kecamatan Mawasangka Kabupaten Buton Tengah. Sapa Laut Vol. 2(3), pp. 79 - 87 (2017)

[13] Kulsum, I., Khakhim, N.: Aplikasi Penginderaan Jauh dan Sistem Informasi Geografis Untuk Monitoring Perubahan Garis Pantai di Pesisir Kabupaten Pasuruan, Kabupaten Sidoarjo dan Kota Surabaya. JURNAL BUMI INDONESIA Vol 7(3), pp. 1-9 (2018)

[14] Aryastana, P., Eryani, I., Candrayana, K.: Perubahan garis pantai dengan citra satelit di Kabupaten Gianyar. Paduraksa 5(2), pp. 70-81 (2016)

[15] Nugraha, I., Karang, I., Dharma, I.: Studi Laju Perubahan Garis Pantai di Pesisir Tenggara Bali Menggunakan Citra Satelit Landsat (Studi Kasus Kabupaten Gianyar dan Klungkung). Journal of Marine and Aquatic Sciences 3(2), pp. 204-214 (2017)

[16] Aryastana, P., Ardantha, I., Agustini, N.: Analisis Perubahan Garis Pantai dan Laju Erosi di Kota Denpasar dan Kabupaten Badung dengan Citra Satelit SPOT. Jurnal Fondasi 6(2), pp. 100-111 (2017)

[17] Aryastana, P., Ardantha, I., Candrayana, K.: Coastline Change Analysis and Erosion Prediction using Satellite Images. In : MATEC Web of Conferences, Bandung, Vol. 197, pp.13003 (2018)

[18] Aryastana, P., Ardantha, I., Rahadiani, A.: Pemanfaatan Citra Satelit SPOT dalam Analisis Perubahan Garis Pantai di Kabupaten Jembrana. In : Konferensi Nasional Teknik Sipil (KoNTekS 12), Batam (2018)

[19] Aryastana, P., Ardantha, I., Nugraha, A., Candrayana, K.: Coasline Changes Analysis in Buleleng Regency by using Satellite Data. In : The 1st Warmadewa University International Conference on Architecture and Civil Engineering, Denpasar, pp.106-113 (2017)

[20] Aryastana, P., Ardantha, I. M., Rahadiani, A. A. S., Candrayana, K.: Deteksi Perubahan Garis Pantai di Kabupaten Karangasem dengan Penginderaan Jauh. Jurnal Fondasi 7(2), pp. 94-104 (2018) 